\title{
Effects of a cationic detergent on the gills and blood chemistry of rainbow trout Salmo gairdneri
}

\author{
P. Byrne, D. Speare, H. W. Ferguson* \\ Fish Pathology Laboratory, Department of Pathology, Ontario Veterinary College, University of Guelph, Guelph, Ontario, \\ Canada N1G 2W1
}

\begin{abstract}
Rainbow trout 23 to $30 \mathrm{~cm}$ in fork length were exposed to various concentrations (1 to $40 \mathrm{ppm}$ ) of a cationic, quaternary ammonium compound, Zephiran. Three ppm was used as a reference value, as this level is recommended at the water hardness found in Southern Ontario (Canada). Gills were examined using light microscopy, scanning and transmission electron microscopy. Changes were observed in gills from fish exposed to all concentrations of Zephiran, becoming more severe as the concentration and/or number of exposures increased. Gills were severely spongiotic and necrotic, and there was much lamellar fusion through apposition. Membrane vesiculation, hydropic degeneration, and exfoliation of lamellar and interlamellar epithelium were also present. Blood chemistry was examined following the second exposure of fish to $3 \mathrm{ppm}$ Zephiran. Haematocrit, serum protein and serum albumin concentrations increased significantly, whereas sodium, chloride and magnesium concentrations decreased; phosphorus, calcium and potassium levels did not change significantly. It is suggested that fish became hypoxic as a result of damage to the gills and that this resulted in a respiratory acidosis causing loss of serum water to the hyperosmotic extravascular tissues. Sodium and chloride were probably lost to the surrounding water via diffusion through the damaged lamellar epithelium. The dramatic drop in sodium and chloride concentration corroborates the severity of lesions seen histologically and ultrastructurally following exposure to Zephiran. In conclusion, the use of Zephiran in the treatment of fish bacterial diseases (e.g. bacterial gill disease) is not recommended in light of the severe changes which follow exposure to therapeutic concentrations.
\end{abstract}

\section{INTRODUCTION}

Fish gills are a multifunctional tissue involved in respiration, osmoregulation, acid-base regulation and excretion (Heisler 1984, Isaia 1984, Randall \& Daxboeck 1984, de Renzis \& Bornancin 1984). For this reason, functional impairment of gills caused by protozoan and metazoan pathogens, or by chemical irritants, can seriously jeopardize the health of the fish.

A group of quaternary ammonium compounds, the cationic, surface-active alkyldimethylbenzylammonium chloride detergents (e.g. Zephiran") have been used for years in the treatment of various fish diseases, especially bacterial gill disease (Rackley 1946, Herwig 1979). In spite of their extensive usage, large variation in suggested dose levels ( 1 to $500 \mathrm{ppm}$ ), and the sometimes high mortality associated with treatment, there are few data on the influence of Zephiran-related com-

- Addressee for correspondence

- Winthrop Laboratories pounds on gill architecture. By contrast, there has been substantial research, including the pioneering work of Schmid \& Mann (1961) on the pathological changes caused by anionic detergents, especially in gill tissues (Lemke \& Mount 1963, Abel \& Skidmore 1975, Mallatt 1985)

In the present study, Zephiran was used to examine the effects of a cationic detergent upon the blood chemistry and tissues (primary gills) of rainbow trout Salmo gairdneri.

\section{MATERIALS AND METHODS}

Maintenance of fish. Rainbow trout used in this study were 23 to $30 \mathrm{~cm}$ in fork length (standard length). Fish were held for at least $5 \mathrm{wk}$ under laboratory conditions before the start of the experiment, and were fed commercial food pellets twice weekly. Food was withheld beginning at least $1 \mathrm{~d}$ before experimentation. Trout were kept in 601 cubic white tanks, and/or in larger 
$650 \mathrm{lgreen}$ circular tanks depending on the number of fish used for specific experiments. Tanks were individually aerated, and were provided with a flowthrough water supply. Water temperature ranged from 8.5 to $10.0^{\circ} \mathrm{C}$. The $\mathrm{pH}$ was ca 7.8 . Water hardness measured $117 \mathrm{mg} \mathrm{l}^{-1}$ as $\mathrm{CaCO}_{3}$, and dissolved oxygen was always greater than $8.0 \mathrm{mgl}^{-1}$ The photoperiod was $12 \mathrm{~h}$ light and $12 \mathrm{~h}$ dark supplied by fluorescent lights.

Exposure to Zephiran solution. The effects of different concentrations of a cationic alkyldimethylbenzylammonium chloride solution (Zephiran) upon fish tissues, most notably gills, and serum chemistry were examined. Multiple exposures were also examined, as this can occur in practice when treating particularly resistant diseases. Three ppm Zephiran was used as the reference value as this concentration is the recommended level at the water hardness found in Southern Ontario.

Stock Zephiran was in a $21.3 \%$ aqueous solution (Winthrop Laboratories). In most cases, exposure of fish to various concentrations of Zephiran lasted for $1 \mathrm{~h}$. Exceptions to this occurred during exposures to high concentrations of 10 to $40 \mathrm{ppm}$, when manifestation of severe clinical signs necessitated the removal and necropsy of fish before the $1 \mathrm{~h}$ exposure period had elapsed.

Whole blood was collected, and/or a necropsy was performed on fish subjected to various exposure levels in this study. Necropsies were normally done $1 \frac{1}{2}$ to $4 \mathrm{~h}$ after the end of the exposure period. Several procedures involved re-exposing fish to low levels of Zephiran for additional $1 \mathrm{~h}$ periods. These multiple exposures of 2 or 3 times took place $24 \mathrm{~h}$ apart.

Serum chemistry was analysed from fish that had been exposed twice to 3 ppm Zephiran. Fifty fish were exposed simultaneously in a $650 \mathrm{I}$ tank on 2 occasions, $24 \mathrm{~h}$ apart. At the completion of the second exposure period, fish were randomly placed into 5 tanks (56l) with 10 fish placed into each tank. Tanks represented 1 sample with 10 replicates (fish) per sample. Samples ( $n=10$ ) were then taken at $1 \mathrm{~h}$ intervals, beginning immediately following the second exposure. Samples involved the collection of blood from each of the 10 fish, and periodically a necropsy of several fish was also taken so that tissues could be saved for histological study.

Histopathology and serum analysis. Prior to the removal of blood, or necropsy, fish were anaesthetized with tricaine methanesulfonate (MS-222, Crescent Research Chemicals, Phoenix, AR, USA). Blood was collected from the caudal vein by hypodermic needle and syringe. Heparinized microhaematocrit tubes were used to determine haematocrit levels. Blood was stored at $4^{\circ} \mathrm{C}$ for 5 to $10 \mathrm{~h}$, and allowed to clot. Blood was then centrifuged, and the serum collected, frozen, and stored at $-20^{\circ} \mathrm{C}$ until analysis. Haemolysis was not seen. Sodium, potassium, and chloride ions were analysed with a Nova Electrolyte Analyzer 5 (Nova Biomedical, MA, USA). Analyses of calcium, phosphorus, total protein, albumin, albumin/globulin ratio, and magnesium were done by a DACOS (Discrete Analyzer with Continuous Optical Scanning, Coulter Electronics of Canada, Ltd). Osmolality was analyzed using an osmometer (The Advanced Micro-Osmometer Model 3MO, Advanced Instruments, Inc., Needham Heights, MA, USA)

Prior to necropsy, fish were killed by severing the spinal cord behind the head. Blood, when collected, was taken before necropsy. Tissues from individual fish were processed for light, and/or electron microscope examination. Tissues for light microscopy were fixed in Bouin's fluid for $24 \mathrm{~h}$, transferred to $70 \%$ alcohol and then processed routinely to paraffin blocks. Tissues sampled included eye, axial muscle and epidermis, gastrointestinal tract, heart, liver, spleen, anterior and posterior kidney and pancreas. Paraffin sections were cut at $5 \mu \mathrm{m}$ and stained with haematoxylin and eosin. Tissues for electron microscopy were fixed in a $2.5 \%$ glutaraldehyde in a $0.1 \mathrm{M}$ phosphate buffer (total osmolality ca $320 \mathrm{mOsm}$ ) and postfixed in $1.0 \%$ osmium tetroxide in a $0.1 \mathrm{M}$ phosphate buffer. Tissues for transmission electron microscopy were then dehydrated in a graded acetone series, and embedded in Epon. Sections $1 \mu \mathrm{m}$ thick were stained with heated methylene blue, and ultrathin sections were stained with uranyl acetate and lead citrate. Tissues for scanning electron microscopy were dehydrated with graded ethanols, critical-point dried, and coated with gold palladium.

Statistics. Results from the blood chemistry were analysed using analysis of variance (ANOVA), and when significant, the treatment means were compared using the Tukey-Kramer multiple pairwise comparison procedure. The level of significance was $95 \%<\alpha=$ $5 \%)$.

\section{RESULTS}

Following exposure to various concentrations of Zephiran, lesions were found only on branchial tissue. Other tissues (i.e. eye, axial muscle and epidermis, and all visceral organs) appeared normal in the light microscope.

\section{3 ppm Zephiran, 1 exposure}

Gills were moderately to severely spongiotic and necrotic, and there were a few foci of lamellar fusion. Spongiosis was severe in the interlamellar regions and 
mild to moderate within the lamellar epithelium. Spongiosis was associated with expansion of the lymphatic channels and extensive vesiculation of the plasma membranes as seen ultrastructurally. Vesiculation primarily involved lamellar epithelial cells, chloride cell apices and pillar cell flanges. Neutrophils and other leukocytes were seen in some of the dilated extracellular lymphatic spaces, and red blood cells with crenated plasma membranes were present in some pillar cell channels. Many lamellar epithelial cells demonstrated marked hydropic degeneration and many were in various stages of necrosis and exfoliation, either individually or occasionally as entire layers. There were many sites on the lamellae where poorly micro-ridged epithelial cells were emerging to replace exfoliated superficial cells.

\section{3 ppm Zephiran, 2 and 3 exposures}

Gills showed severe spongiosis (Fig, 1) and necrosis, and there was much lamellar fusion (Fig. 2). Spongiosis and necrosis were more widespread and severe than in gills exposed to a single dose of $3 \mathrm{ppm}$ Zephiran. Related lesions were also more severe. These included cell membrane vesiculation, exfoliation and hydropic degeneration of lamellar and interlamellar epithelium (Fig. 3), and delamination of lamellar epithelium

Figs. 1 and 2. Salmo gairdneri. Light micrographs of gill lamellae from rainbow trout subjected to three $1 \mathrm{~h}$ exposures of $3 \mathrm{ppm}$ Zephiran over a $48 \mathrm{~h}$ period, and sampled ca $2 \mathrm{~h}$ following the last exposure. Fig. 1. Exfoliation and delamination of the lamellar epithelium. $(\times 500)$. Fig 2. Lamellar fusion and marked dilation within the interlamellar region (arrow). $(\times 500)$

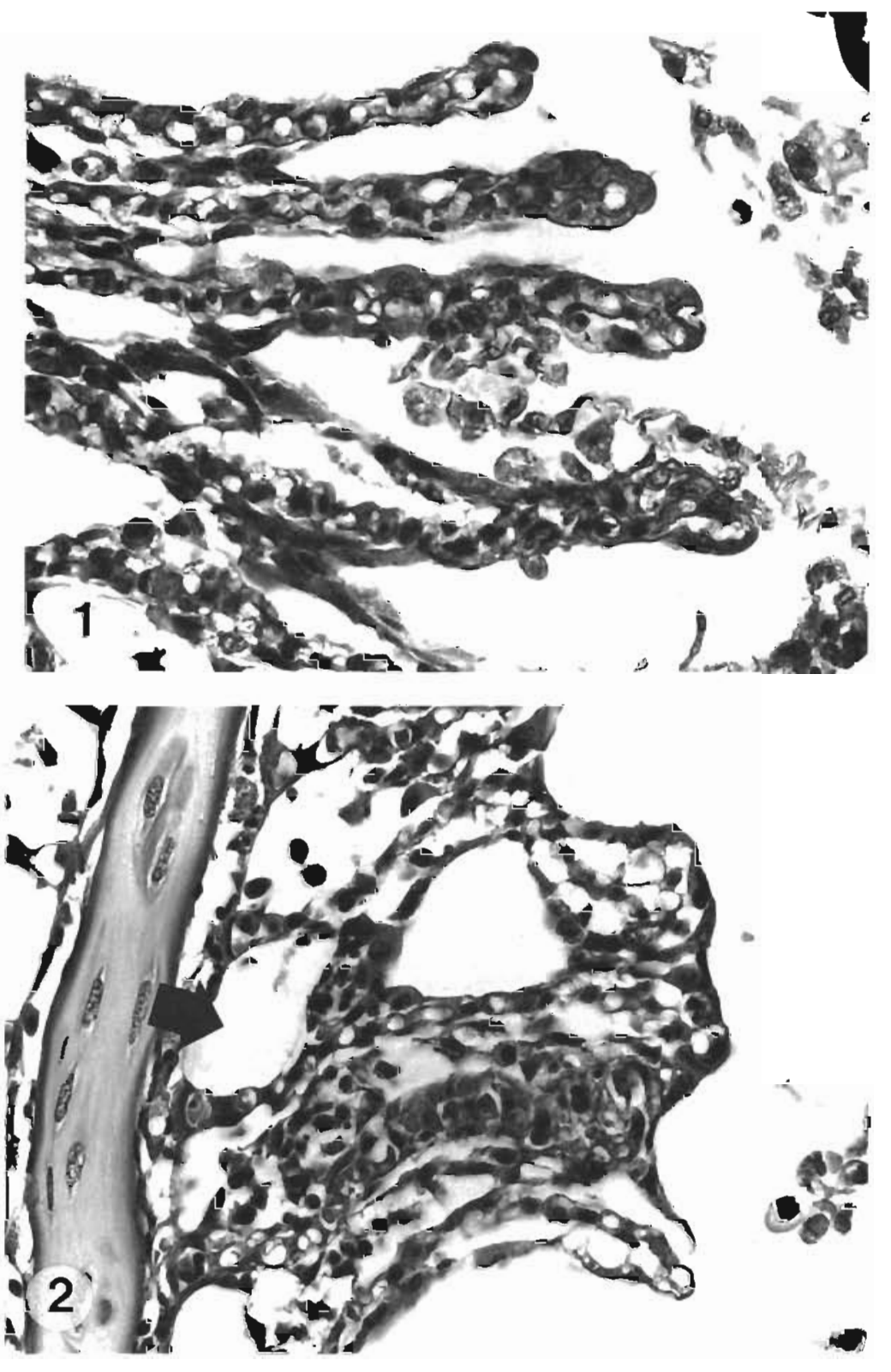


(Fig. 4). Cells beneath sloughed epithelium were characterized by their reduced number of micro-ridges (Fig. 5). Lamellar fusion, only occasionally seen in gills from a single Zephiran exposure ( 3 ppm), was extensive and often involved groups of lamellae. Fusion was more common in fish subjected to 3 exposures of Zephiran. Apposition occurred frequently, but not exclusively, along the distal region of the lamellae. Epithelial cells from adjacent, apposed lamellae were frequently fused through a re-organization of the fibrillar cytoskeleton into tight junctions and desmosomes.
All fish survived 3 exposures to 3 ppm Zephiran, but showed severe signs of distress towards the end of the third exposure. Many of these fish began to lose orientation and to have exaggerated branchial movements, and they became lethargic.

\section{1 ppm Zephiran, 1 exposure}

Most gill tissue appeared histologically normal, except for moderate swelling of some lamellar epithelial cells and mild, focal spongiosis of some interlamel-
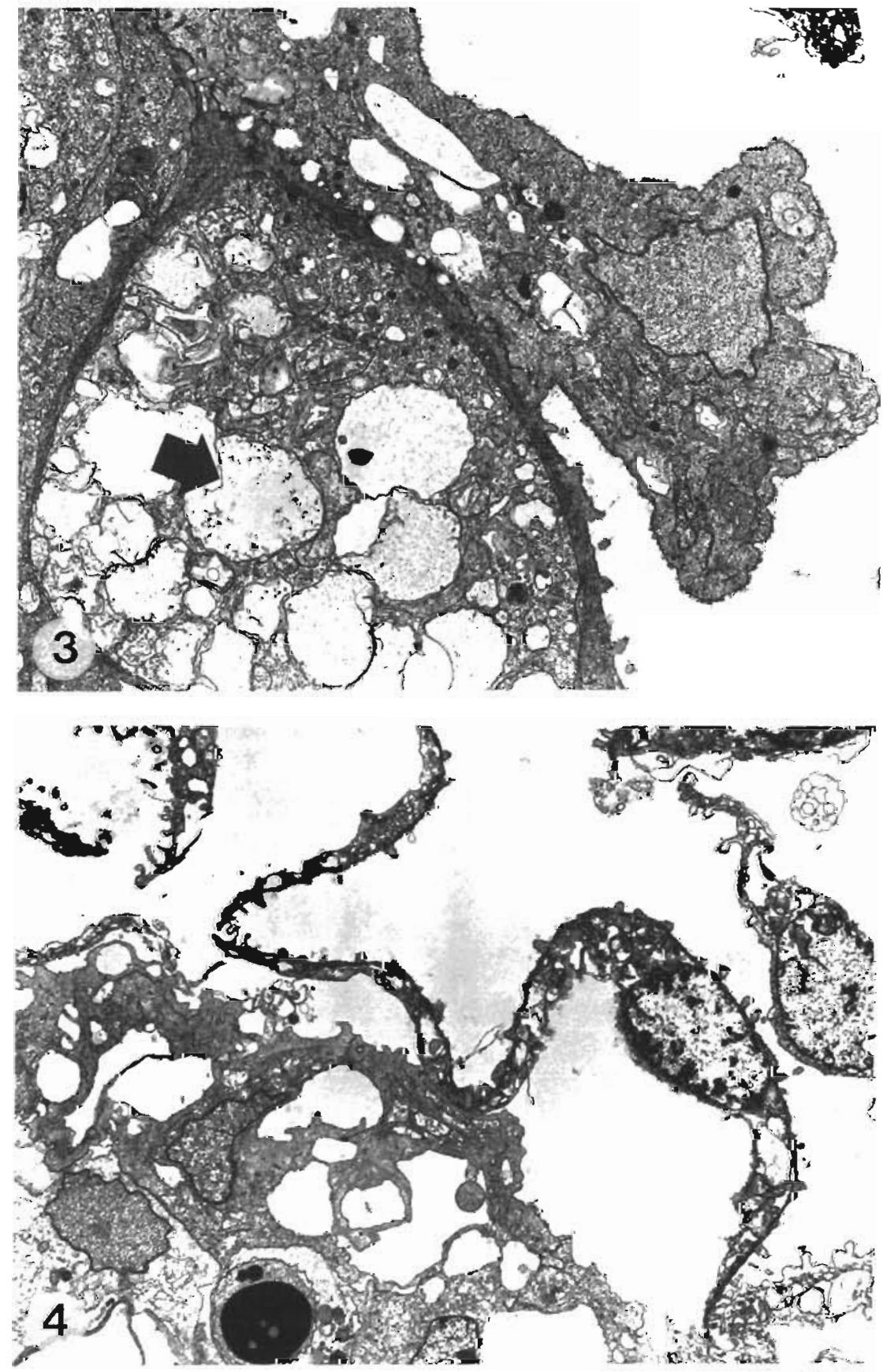

Figs. 3 and 4. Salmo gairdneri. Electron micrographs of gill lamellae from rainbow trout subjected to two $1 \mathrm{~h}$ exposures of $3 \mathrm{ppm}$ Zephiran over a $24 \mathrm{~h}$ period and sampled $24 \mathrm{~h}$ following the last exposure Fig. 3. Degenerate chloride cell with high amplitude swelling of mitochondria (arrow) and dilation of endoplasmic reticulum. $(\times 4000)$. Fig. 4 . Entire sheet of lamellar epithelial tissue in the process of delaminating. $(\times 2000)$ 
lar epithelium. Ultrastructurally, spongiosis was seen within the lamellar and interlamellar epithelium. There was a moderate increase in the number of small and large autolysosomes. Swollen mitochondria were seen in some chloride cells.

\section{1 ppm Zephiran, 2 and 3 exposures}

Mild to moderate spongiosis and hydropic degeneration and some cell necrosis were seen. Swelling was most common on the lamellar epithelium (Fig. 6). Ultrastructurally this was seen to disrupt the microridge structure, most noticeably at the apices of the lamellar epithelial cells. Some chloride and lamellar epithelial cells were in various stages of degeneration as indicated by swelling, by expansion of the basolateral spaces (chloride cells only), and by the presence of autolysosomes (Fig. 7). There was an increased number of autolysosomes compared to gills from a single exposure of $1 \mathrm{ppm}$ Zephiran. Necrotic lamellar
Fig. 5. Salmo gairdneri. Scanning electron micrograph of gill lamellae from rainbow trout subjected to 2 exposures of $3 \mathrm{ppm}$ Zephiran over a $24 \mathrm{~h}$ period and sampled $24 \mathrm{~h}$ following the last exposure. Note presence of cells with greatly reduced numbers of micro-ridges (arrow). These probably represent immature cells replacing sloughed ones. $(\times 2900)$

Fig. 6. Salmo gairdneri. Scanning electron micrograph of gill lamellae from rainbow trout subjected to 3 exposures of $1 \mathrm{ppm}$ Zephiran over a $48 \mathrm{~h}$ period and sampled 24 $h$ following the last exposure. Individual lamellar epithelial cells appear swollen as a result of spongiosis and hydropic degeneration of underlying cells
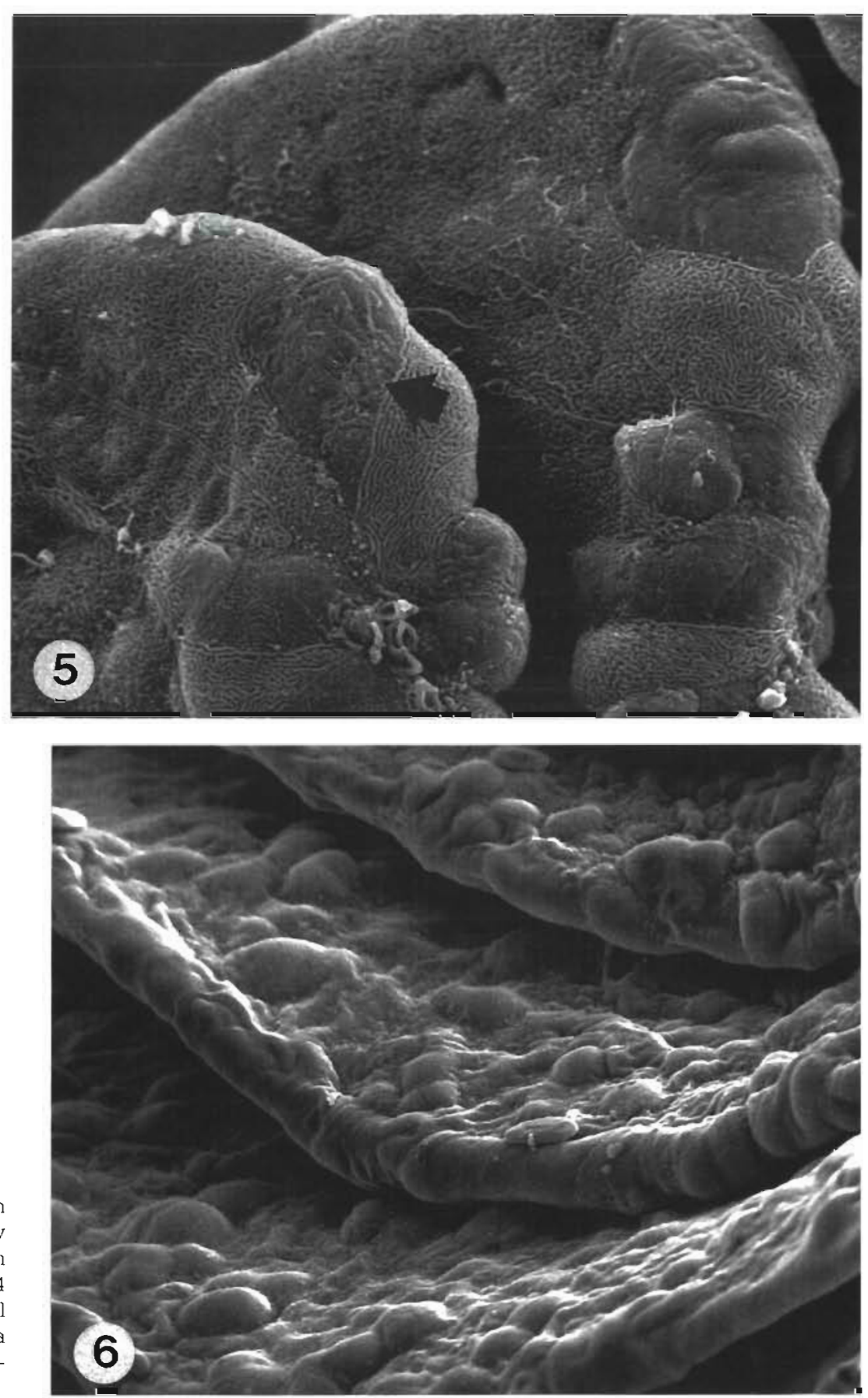


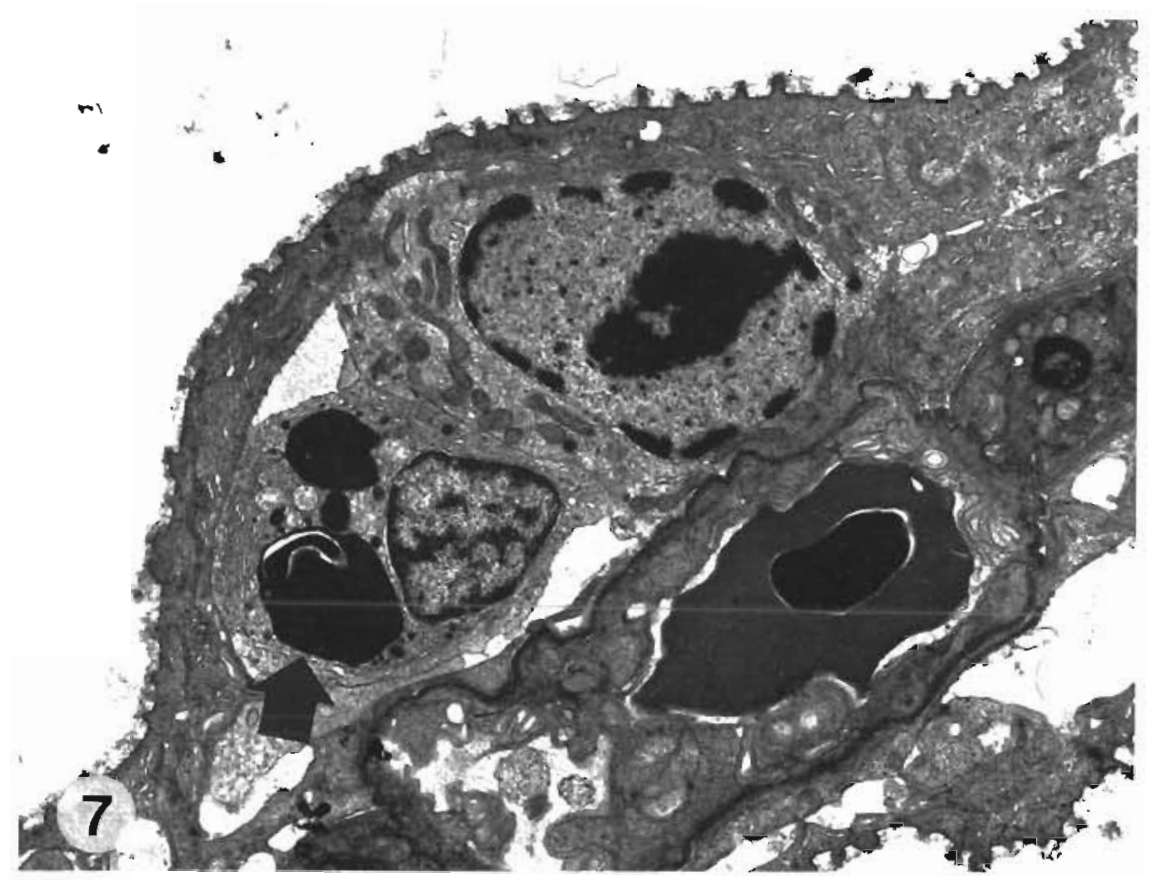

Fig. 7 Salmo gairdneri. Electron micrograph of gill lamellae from rainbow trout subjected to two $1 \mathrm{~h}$ exposures of $1 \mathrm{ppm}$ Zephiran over a $24 \mathrm{~h}$ period and sampled $24 \mathrm{~h}$ following the last exposure. Note degenerating cell with autolysosomes (arrow). ( $\times 4000)$ epithelial cells with pyknotic nuclei were occasionally seen both in situ and in various stages of exfoliation. Margination of chromatin was seen ultrastructurally in necrotic cells as was moderate vesiculation, associated mainly with pillar cell flanges.

\section{5 ppm Zephiran, 1 exposure}

All fish survived the $1 \mathrm{~h}$ exposure period, but clinical signs, similar to those described following three exposures to $3 \mathrm{ppm}$ Zephiran, were encountered towards the end of the exposure period.

Lesions were similar to those described in fish from multiple exposures to 3 ppm Zephiran. However, spongiosis was not as severe, fewer autolysosomes were present and no lamellar fusion was seen. Necrosis was more severe and haemolysis of erythrocytes (and possibly other blood cell types) was abundant in the central venous sinus and pillar cell channels. The proximal region of the lamellar epithelium delaminated from the underlying pillar cell network and the distal lamellar region was expanded due to hydropic degeneration, and to an increased number of cells. The basement membrane was intact, but there was an increase in width and electron density when examined ultrastructurally.

\section{$10,20,30$ and 40 ppm Zephiran (35 to $60 \mathrm{~min}$ )}

It became necessary to kill and sample most fish before the $1 \mathrm{~h}$ exposure period had ended because of the extreme distress shown by the fish.

Lesions observed were similar to those changes in fish exposed to $5 \mathrm{ppm}$ Zephiran. However, necrosis, exfoliation (Figs. 8, 9 and 10) and hydropic degeneration of lamellar, interlamellar and filamental epithelia were much more extensive and severe. Haemolysis in the central venous sinus was more severe than at 5 ppm, and in addition, haemolysis was also observed in the expanded (spongiotic) interlamellar lymphatics and other extracellular spaces of the interlamellar region. Eosinophilic granular cells of the filament were undergoing degranulation, degeneration, and necrosis. Some pillar cell channels appeared congested; this was often associated with a coalescense of channels due to obliteration of portions of the pillar cell network.

\section{Serum chemistry, 3 ppm Zephiran, 2 exposures}

An immediate decrease occurred in sodium ( $p \leq$ $0.0001)$ and chloride $(p \leq 0.0001)$ concentrations and in osmolality ( $p=0.0074)$ following a second Zephiran exposure (3 ppm) (Table 1). Magnesium concentration also decreased, but only the last 2 samples were significantly lower than the control $(p=0.0015)$. Total serum protein $(p=0.02)$, serum albumin $(p=0.0077)$ and haematocrit $(p=0.0344)$ increased significantly. Changes involving potassium, calcium, phosphorus and albumin/globulin ratio were not significant $(p \geq 0.05)$.

\section{DISCUSSION}

This paper provides evidence of acute changes in gill tissues and serum chemistry of rainbow trout exposed 


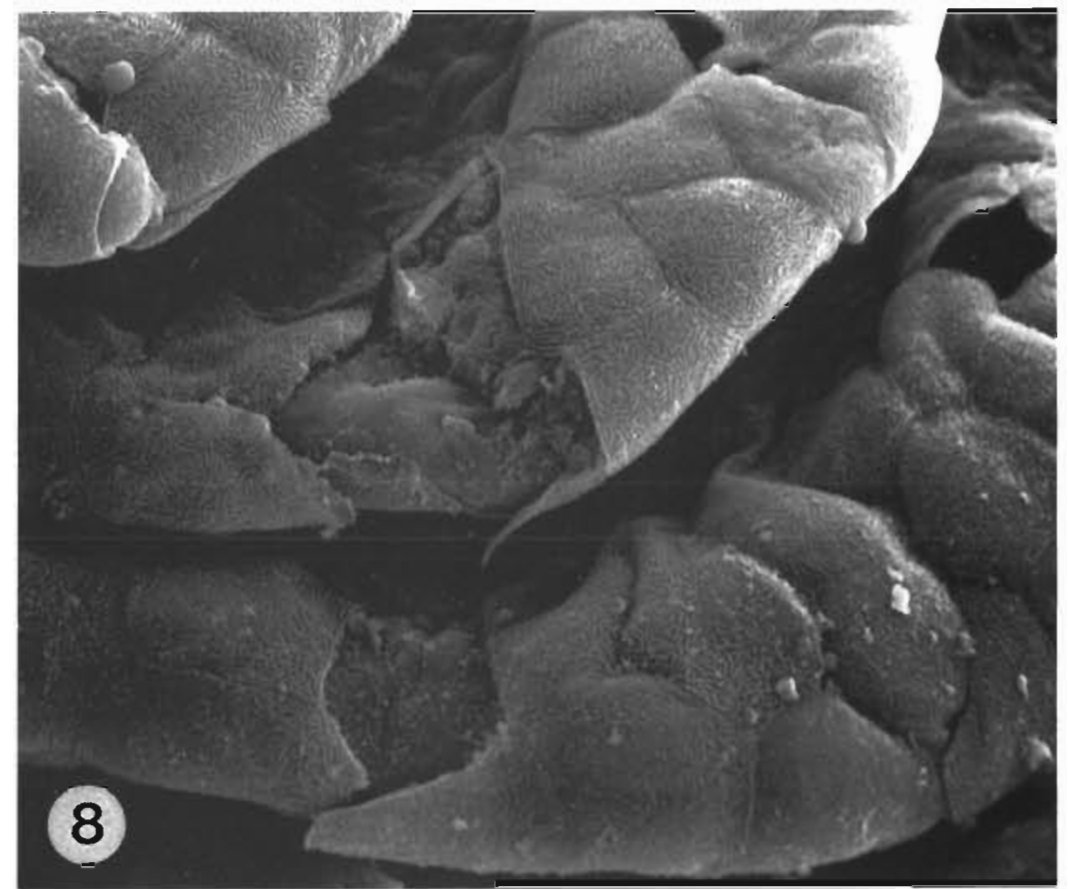

Figs. 8 and 9. Salmo gairdneri. Scanning electron micrographs of gill lamellae from rainbow trout exposed to $40 \mathrm{ppm}$ Zephiran for ca $35 \mathrm{~min}$. Fig. 8. Note areas where lamellar epithelial cells are missing revealing the underlying non micro-ridged cells. Cell borders are accentuated because of spongiosis and hydropic degeneration of underlying tissues. $(\times 1400)$. Fig. 9. Closeup of area from where a lamellar epithelial cell has exfoliated. Note disrupted microridge pattern of surrounding epithelial cells that still remain. $(\times 4400)$

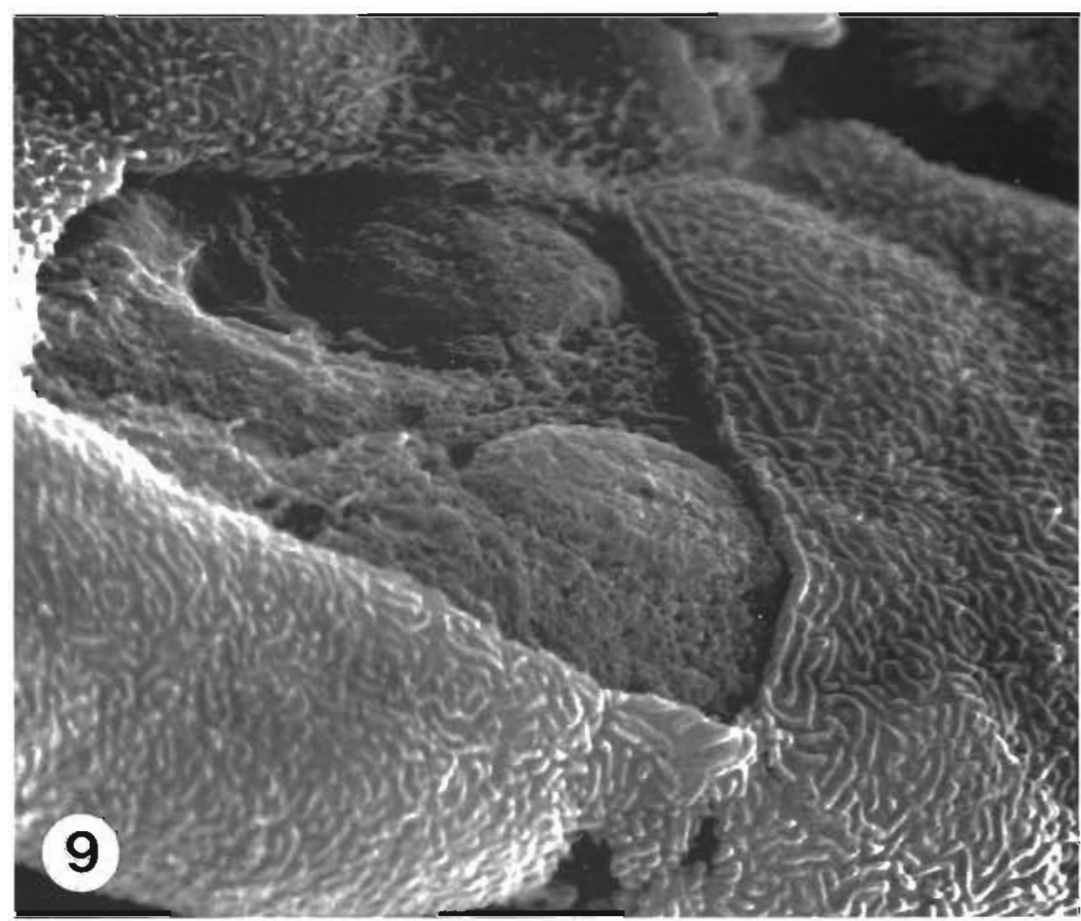

to relatively low doses ( 1 to $5 \mathrm{ppm}$ ) of a cationic detergent (Zephiran) at, or at slightly greater than, therapeutic concentrations (i.e. 1 to $3 \mathrm{ppm}$ ) recommended for the water hardnesses commonly found in Southern Ontario, Canada. Other tissues (i.e. nonbranchial epidermis, muscle and visceral organs) were not adversely affected. At higher concentrations (10 to $40 \mathrm{ppm}$ ), fish were usually sampled before the $1 \mathrm{~h}$ exposure period had ended; nevertheless, it was found that the gills had undergone severe changes, thereby confirming the clinical presentation of severe respiratory distress. The findings help explain many of the adverse effects of this and similar agents which often follow their use as treatments for bacterial and other gill diseases.

The range of lesions observed in this study are not unique to trout exposed to Zephiran; they have been reported previously in fish exposed to other branchial 


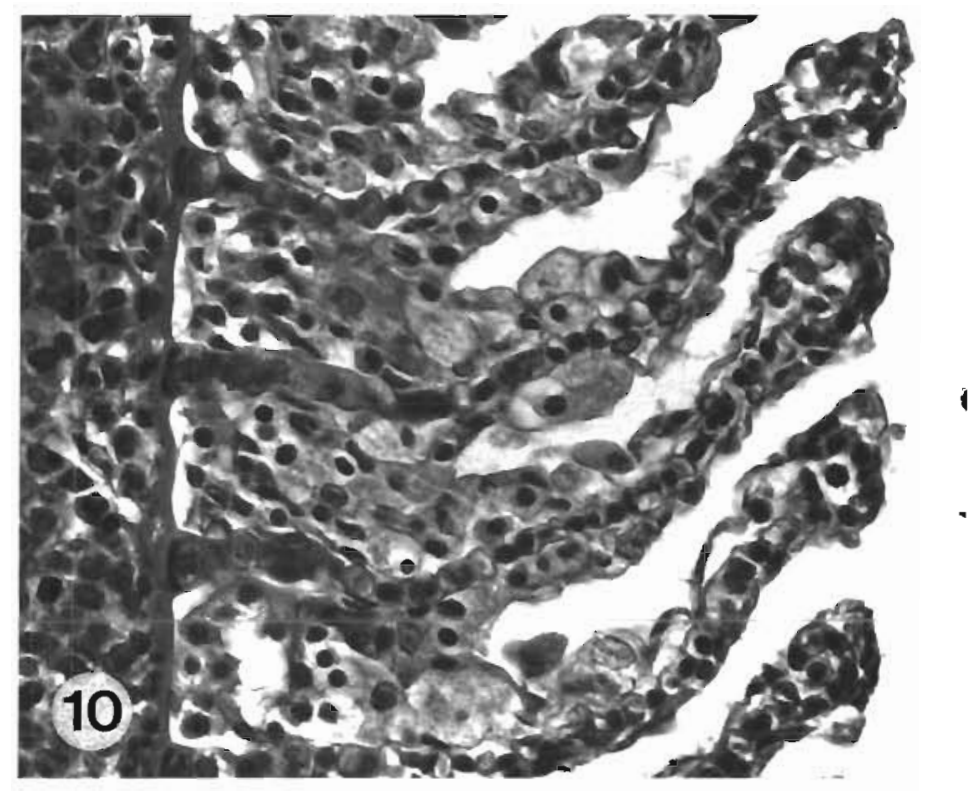

Fig. 10. Salmo gairdneri. Light micrograph of gill iameilae from rambow trout exposed to $10 \mathrm{ppm}$ Zephiran for ca $45 \mathrm{~min}$. Note severe hydropic degeneration and necrosis of the lamellar and interlamellar epithelium with some spongiosis also present. $(\times 500)$

irritants (Mallatt 1985). This is not surprising in light of the fact that gill lesions pathognomonic for particular agents or toxicants are rare (Goldes et al. 1988).

The mechanism(s) by which Zephiran produces its toxic effect is not well understood at the structural level. From studies involving bacteria (e.g. Baker et al. 1941, Glassman 1948, Hugo 1967) it is known that ionic detergents cause the breakdown of various cellular enzyme systems and the disorganization of cell membranes. In the present study, changes to plasma membranes were common, but even in necrotic cells, membranes were not completely disrupted. These findings are therefore similar to those reported by Abel \& Skidmore (1975) in trout gills exposed to an anionic detergent. Crenation of the plasma membrane of erythrocytes was also seen. This might have been due to direct Zephiran exposure, or as a response secondary to changes in osmolality. Alternatively, respiratory and other intracellular enzyme systems may have been directly affected by the detergent, similar to mechanisms reported from studies involving bacteria and various detergents.

At low detergent concentrations, plasma membranes can be partially disrupted, without necessarily being completely solubilized (Jørgensen 1975). Nevertheless, there is increasing permeability, which can allow fluxes of various ions and macromolecules (Kreibich et al. 1974). Ionic detergents can denature proteins including those associated with the plasma membrane. ATPases, which are large integral membrane proteins, are important for the maintenance of the electrochemical gradient across cell membranes and for the active uptake of sodium, chloride, and probably other inorganic electrolytes from the freshwater environment
(Eddy 1982). Interestingly, however, they are one of the last proteins to be affected during membrane dissolution by a detergent (Jørgensen 1975) and accordingly they may have been spared destruction by the Zephiran. If so, however, their continued functioning was not enough to prevent the Zephiran-induced net loss of sodium and chloride. The hydropic degeneration and spongiosis of the lamellar and the interlamellar epithelium was probably a result of water influx caused by increased membrane and junctional porosity. Increased porosity may have led to influx of Zephiran into the cytoplasm where its toxic action could be directed at organelles and other intracellular components as discussed previously.

Compared to plasma membranes, the relative stability of the basement membrane over the course of various Zephiran exposures was probably due to its different composition. Basement membrane is composed primarily of mucopolysaccharides, and in gill lamellae it is intimately associated with collagen fibers on the serosal surface (Bird \& Eble 1979). Consequently, with few lipid components present, there appear to be few sites to which the alkyl radical on the detergent molecule can bind or associate (James 1964). The intact basement membrane may have helped to maintain some structural integrity of the pillar cell network in the face of severe widespread necrosis of the lamellar epithelium.

The overall negative surface charge presumably present on the glycocalyx of the lamellar epithelium, as in other animal cell membranes (Bretscher \& Raff 1975), may have helped promote contact between Zephiran (a cation) and the gill surface, thus augmenting toxic effects. The cationic properties of a heavy metal and an 
Table 1. Salmo gairdneri. Values of various constituents of the blood of rainbow trout, exposed twice to 3 ppm Zephiran. Values are means $\pm \mathrm{SE}_{i} n$ : sample size; control and values taken $1,2,3$ and $4 \mathrm{~h}$ following the second exposure. Values with the same letter are not significantly different.

\begin{tabular}{|c|c|c|c|c|c|}
\hline \multirow[t]{2}{*}{ Constituent } & \multirow[t]{2}{*}{ Control } & \multicolumn{4}{|c|}{ Time after exposure } \\
\hline & & $1 \mathrm{~h}$ & $2 \mathrm{~h}$ & $3 \mathrm{~h}$ & $4 \mathrm{~h}$ \\
\hline $\begin{array}{l}\mathrm{Na} \\
(\mathrm{mmol} \mathrm{1}\end{array}$ & $\begin{array}{l}160.9^{c} \\
\pm 0.4 \\
n=9\end{array}$ & $\begin{array}{l}141.9^{4} \\
\pm 1.9 \\
n=10\end{array}$ & $\begin{array}{l}146.2^{\mathrm{d}} \\
\pm 1.1 \\
n=7\end{array}$ & $\begin{array}{l}142.0^{d} \\
\pm 2.5 \\
n=8\end{array}$ & $\begin{array}{l}144.0^{\circ} \\
\pm 1.3 \\
n=8\end{array}$ \\
\hline $\begin{array}{l}\mathrm{K} \\
\left(\mathrm{mmol} \mathrm{1} 1^{-1}\right)\end{array}$ & $\begin{array}{l}0.51 \\
\pm 0.15 \\
n=9\end{array}$ & $\begin{array}{l}1.12 \\
\pm 0.31 \\
n=10\end{array}$ & $\begin{array}{l}0.75 \\
\pm 0.09 \\
n=7\end{array}$ & $\begin{array}{l}1.16 \\
\pm 0.19 \\
n=8\end{array}$ & $\begin{array}{l}1.09 \\
\pm 0.23 \\
n=8\end{array}$ \\
\hline $\begin{array}{l}\mathrm{Cl} \\
\left(\mathrm{mmol} \mathrm{l}^{-1}\right)\end{array}$ & $\begin{array}{l}127.4 \\
\pm 0.6 \\
n=9\end{array}$ & $\begin{array}{l}99.9^{a} \\
\pm 3.5 \\
n=10\end{array}$ & $\begin{array}{l}104.1^{a} \\
\pm 1.8 \\
n=7\end{array}$ & $\begin{array}{l}98.1^{a} \\
\pm 3.6 \\
n=8\end{array}$ & $\begin{array}{l}99.0^{\mathrm{a}} \\
\pm 1.8 \\
n=8\end{array}$ \\
\hline $\begin{array}{l}\mathrm{Ca} \\
\left(\mathrm{mmol} \mathrm{l^{-1 }}\right)\end{array}$ & $\begin{array}{l}3.36^{\circ} \\
\pm 0.09 \\
n=10\end{array}$ & $\begin{array}{l}3.47 \\
\pm 0.22 \\
n=8\end{array}$ & $\begin{array}{l}3.50 \\
\pm 0.18 \\
n=8\end{array}$ & $\begin{array}{l}3.60 \\
\pm 0.28 \\
n=7\end{array}$ & $\begin{array}{l}3.60 \\
\pm 0.23 \\
n=7\end{array}$ \\
\hline $\begin{array}{l}\mathrm{P} \\
\left(\mathrm{mmol} \mathrm{l}^{-1}\right)\end{array}$ & $\begin{array}{l}6.27^{\circ} \\
\pm 0.18 \\
n=10\end{array}$ & $\begin{array}{l}5.38 \\
\pm 0.29 \\
n=8\end{array}$ & $\begin{array}{l}5.36 \\
\pm 0.25 \\
n=8\end{array}$ & $\begin{array}{l}5.94 \\
\pm 0.77 \\
n=6\end{array}$ & $\begin{array}{l}4.99 \\
\pm 0.22 \\
n=6\end{array}$ \\
\hline $\begin{array}{l}\text { Total protein } \\
\left(\mathrm{g}^{-1}\right)\end{array}$ & $\begin{array}{l}40.9^{\mathrm{a}} \\
\pm 1.1 \\
n=10\end{array}$ & $\begin{array}{l}48.9^{a b} \\
\pm 3.4 \\
n=9\end{array}$ & $\begin{array}{l}50.3^{b} \\
\pm 2.2 \\
n=8\end{array}$ & $\begin{array}{l}47.8^{\mathrm{ab}} \\
\pm 1.9 \\
n=9\end{array}$ & $\begin{array}{l}49.7^{\mathrm{ab}} \\
\pm 1.7 \\
n=9\end{array}$ \\
\hline Albumin/globulin & $\begin{array}{l}0.67^{*} \\
\pm 0.04 \\
n=10\end{array}$ & $\begin{array}{l}0.67 \\
\pm 0.02 \\
n=9\end{array}$ & $\begin{array}{l}0.68 \\
\pm 0.03 \\
n=8\end{array}$ & $\begin{array}{l}0.63 \\
\pm 0.02 \\
n=9\end{array}$ & $\begin{array}{l}0.65 \\
\pm 0.01 \\
n=9\end{array}$ \\
\hline $\begin{array}{l}\text { Osmolality } \\
\text { (mOsm) }\end{array}$ & $\begin{array}{l}318.7^{\mathrm{a}} \\
\pm 10.3 \\
n=10\end{array}$ & $\begin{array}{l}290.9^{b} \\
\pm 3.6 \\
n=8\end{array}$ & $\begin{array}{l}290.5^{b} \\
\pm 1.6 \\
n=8\end{array}$ & $\begin{array}{l}296.6^{\mathrm{db}} \\
\pm 3.7 \\
n=10\end{array}$ & $\begin{array}{l}301.2^{\mathrm{ab}} \\
\pm 2.8 \\
n=9\end{array}$ \\
\hline $\begin{array}{l}\mathrm{Mg} \\
\left(\mathrm{mmol} \mathrm{l} \mathrm{l}^{-1}\right)\end{array}$ & $\begin{array}{l}1.47^{\mathrm{a}} \\
\pm 0.07 \\
n=10\end{array}$ & $\begin{array}{l}1.32^{\mathrm{ab}} \\
\pm 0.04 \\
n=9\end{array}$ & $\begin{array}{l}1.48^{\mathrm{ac}} \\
\pm 0.05 \\
n=8\end{array}$ & $\begin{array}{l}1.08^{b} \\
\pm 0.13 \\
n=9\end{array}$ & $\begin{array}{l}1.15^{\mathrm{br}} \\
\pm 0.05 \\
n=8\end{array}$ \\
\hline $\begin{array}{l}\text { Albumin } \\
\left(g^{-1}\right)\end{array}$ & $\begin{array}{l}16.2^{\circ} \\
\pm 0.5 \\
n=10\end{array}$ & $\begin{array}{l}19.4^{\mathrm{b}} \\
\pm 1.3 \\
n=9\end{array}$ & $\begin{array}{l}20.3^{b} \\
\pm 0.7 \\
n=8\end{array}$ & $\begin{array}{l}18.6^{\mathrm{ab}} \\
\pm 0.8 \\
n=9\end{array}$ & $\begin{array}{l}19.6^{\mathrm{b}} \\
\pm 0.5 \\
n=9\end{array}$ \\
\hline $\begin{array}{l}\text { Haematocrit } \\
(\%)\end{array}$ & $\begin{array}{l}43.8^{d} \\
\pm 1.5 \\
n=10\end{array}$ & $\begin{array}{l}49.3^{\mathrm{ab}} \\
\pm 3.1 \\
n=9\end{array}$ & $\begin{array}{l}51.8^{a b} \\
\pm 2.3 \\
n=10\end{array}$ & $\begin{array}{l}52.0^{\mathrm{b}} \\
\pm 1.7 \\
n=10\end{array}$ & $\begin{array}{l}51.3^{\text {ab }} \\
\pm 1.3 \\
n=10\end{array}$ \\
\hline
\end{tabular}

acrylamide flocculant have been implicated as factors responsible for, or augmenting, the toxicity of these compounds on gill lamellae of trout (Daoust et al. 1984, Albassam et al. 1987). Lamellar apposition and necrosis were apparently intensified by the disruption of the net negative surface charge and by promoting contact between the glycocalyx and toxicant, respectively.

Clinicopathological results seem somewhat contradictory, as there was an increase in haematocrit and total protein suggesting haemoconcentration, but a corresponding decrease in serum sodium and chloride concentrations and in osmolality, suggesting a dilution effect. A possible explanation for the latter is that sodium and chloride were lost across the gills because of damage to the lamellar epithelium (Abel 1974,
Albassam et al. 1987). Uptake of sodium and chloride at the gills was probably impaired as well, or insufficient in response to the greatly increased efflux similar to changes reported in trout suffering acid damage to the gills (Wood 1988). Because of their abundance, sodium and chloride are the 2 most important ions affecting osmolality in the blood. Changes occurring with other, less abundant ions (i.e. calcium, phosphorus and potassium) exert minimal osmotic effect, as do changes in macromolecular serum proteins (Duncan \& Prasse 1986) because of the colligative properties involved (Wilson 1982).

The haemoconcentration was probably due to an efflux of plasma water into extravascular spaces in response to an osmotic gradient. This gradient could 
have been set up either by a faster loss of ions from. plasma than from tissues, as seen in trout suffering from environmental acid stress (Wood 1988), or by an increase in tissue osmolality resulting from hypoxiainduced lactate production. Many reports have suggested, or provided evidence, that damage to gill epithelium results in hypoxia caused by inhibition of gas exchange at the gills (Skidmore \& Tovell 1972, Smart 1976, Ellis \& Smith 1983, Spry \& Wood 1984. Malte \& Weber 1985, Albassam et al. 1987). Ellis \& Smith (1983) reported that oedema within the lamellar epithelium extends the blood-water diffusion barrier, thus increasing the diffusional distance, or decreasing the diffusional conductance of oxygen (sensu Malte \& Weber 1985). Also, epithelial lifting (delamination) and fusion of the lamellar epithelium would decrease the available surface area for gas exchange (Skidmore \& Tovell 1972) and increase the diffusional distance for gases. In the present study, hydropic degeneration, spongiosis and delamination of the lamellar epithelium, and lamellar fusion, all could have contributed to an interference with respiratory gas exchange resulting in hypoxia.

Decreased diffusional efficiency, resulting in hypoxia, may have also impeded carbon dioxide efflux, causing hypercapnia (Albassam et al. 1987) and respiratory acidosis. The increased solubility of carbon dioxide over that of oxygen, however, could ameliorate the effects of hypercapnia. Some toxicants may inhibit, or destroy carbonic anhydrase in gill epithelium (Satchell 1984), thus intensifying, or indeed initiating hypercapnia. On the other hand, Randall \& Daxboeck (1984) claim that gill epithelial carbonic anhydrase does not play a significant role in plasma bicarbonate dehydration which leads to the release of carbon dioxide.

Regardless of the severity of hypercapnia the hypoxia presumably caused by the damaged gills would result in an increase in anaerobic metabolism, leading to a decrease in $\mathrm{pH}$, initially intracellularly, and subsequently in the serum and the poorly buffered extraceliular fluid (Wardle 1978, Holeton et al. 1983). Turner et al. (1983) reported that in rainbow trout an osmotic shift from the blood into the intracellular and extracellular fluid compartments, in response to elevated extravascular lactic acid, occurred as a result of exercise-induced hypoxia. Blood thus became dehydrated as a consequence of the osmotic shift. Lactic acid has also been reported to increase in fish during stress (Wardle 1978, Holeton et al. 1983). Consequently, stress of handling may have also contributed towards a possible osmotic shift, in addition to the suspected hypoxia-induced metabolic acidosis. Unlike the rapid release of lactic acid which normally occurs in mammalian muscle under hypoxic conditions (Karlsson
\& Saltin 1971), in fish there is a delay in lactate and proton extrusion into the vascular channels (Wardle 1978). In fact, it is suggested that most lactic acid produced in fish is removed by metabolism in situ (Turner et al. 1983). Even a minor decrease in pH (and therefore increased osmolality) of the extracellular fluid would have a greater impact on serum chemistry than would occur in mammals, because of the smaller blood volume found in fish.

Albassam et al. (1987) reported that a cationic acrylamide flocculant caused severe oedema and necrosis to the lamellar epithelium in rainbow trout. The clinicopathology was strikingly similar to that of the present study in that there was haemoconcentration associated with a decrease in serum sodium and chloride. They also included blood-gas analysis showing hypoxia, hypercapnia and decreased serum $\mathrm{pH}$, which also corroborates the suggestion of an hypoxiainduced acidosis and respiratory hypercapnia in the present study.

In addition to losing serum sodium and chloride to the water, some ions and serum water may have entered the erythrocytes as a result of an adrenalineinduced stress response (Mazeaud \& Mazeaud 1981, Nikinmaa 1982). Adrenaline is mobilized under acidotic conditions, and helps raise erythrocytic intracellular $\mathrm{pH}$. Part of this mechanism involves a swelling of the erythrocytes and a net uptake of sodium and chloride by these cells. As a result, there is a net shift of sodium, chloride and water from plasma to red cells, and a shift of protons from red cells to plasma. A reduction in serum $\mathrm{pH}$ has been reported in many studies involving stressed fish (Railo et al. 1985). There are many reports implicating various kinds of stressors (e.g. handling stress and toxic damage to gills) as causing erythrocytes to swell and resulting in increased haematocrit, without necessarily an increase in haemoglobin (Railo et al. 1985, Malte 1986, Albassam et al. 1987, Goss \& Wood 1988). By contrast with the $\beta$ adrenergic induced swelling of erythrocytes, blood cells in our study may simply have become swollen in response to reduced serum osmolality (e.g. Milligan \& Wood 1982). The contribution toward the elevated haematocrit made by mobilization of erythrocytes is unknown. Erythrocyte volumes and counts, haemoglobin concentration, and serum $\mathrm{pH}$ were not examined, and the exact nature of the increase in haematocrit is therefore unknown.

The severity of lesions and serum chemistry changes are evidence of the extreme toxicity of Zephiran. These conclusions support our experience that it is indeed too toxic for most practical considerations. Certainly its use for treating fish diseases has diminished, in favour of more pathogen-specific agents. Zephiran-exposed gills may in the future, provide a working model from which 
to evaluate with more depth the clinical manifestations of acute changes in gill structure caused by various irritants and pathogens (e.g bacterial gill disease).

Acknowledgements. We are grateful to Dr Chris Wood McMaster University, for critically reviewing this manuscript. The Fish Pathology Laboratory is mainly funded by the Ontario Ministry of Agriculture and Food.

\section{LITERATURE CITED}

Abel, P. D (1974). Toxicity of synthetic detergents to fish and aquatic invertebrates. J. Fish Biol. 6: 279-298

Abel, P. D., Skidmore, J. F. (1975). Toxic effects of an anionic detergent on the gills of rainbow trout. Wat. Res. 9: $759-765$

Albassam, M., Moore, J., Sharma, A. (1987). Ultrastructural and clinicopathological studies on the toxicity of cationic acrylamide-based flocculant to rainbow trout. Vet. Pathol. 24: $34-43$

Baker, Z., Harrison, R. W., Miller, B. F. (1941). The bactericidal action of synthetic detergents. J. exp. Med. 74-611-620

Bird, D. J., Eble, A. F. (1979). Cytology and polysaccharide cytochemistry of the gill of the american eel. Anguilla rostrata. Biol. Bull. mar biol. Lab., Woods Hole 157 104-111

Bretscher, M. S., Raff, M. C. (1975). Mammalian plasma membranes. Nature, Lond. 258: 43-49

Daoust, P.-Y., Wobeser, G., Newstead, J. D. (1984). Acute pathological effects of inorganic mercury and copper in gills of rainbow trout. Vet. Pathol. 21: 93-101

Duncan, J. R., Prasse, K. W (1986). Veterinary laboratory medicine, 2nd ean. Iowa State University Press, Ames, p. 89

Eddy, F. B. (1982). Osmotic and ionic regulation in captive fish with particular reference to salmonids. Comp. Biochem. Physiol. 73B: 125-141

Ellis, A. G., Smith, D. G. (1983). Edema formation and impaired $\mathrm{O}_{2}$ transfer in Ringer-perfused gills of the eel, Anguilla australis. J. exp. Zool. 227.371-380

Glassman, H. N. (1948). Surface active agents and their application in bacteriology. Bact. Rev. 12: 105-148

Goldes, S. A., Ferguson, H. W., Moccia, R. D., Daoust, P.-Y (1988). Histological effects of the inert suspended clay kaolin on the gills of juvenile rainbow trout, Salmo gairdneri Richardson. J. Fish Dis. 11: 23-33

Goss, G. G. Wood, C. M. (1988). The effects of acid and acid/ aluminum exposure on circulating plasma cortisol levels and other blood parameters in the rainbow trout, Salmo gairdneri. J. Fish Biol. 32: 63-76

Heisler, N. (1984). Acid-base regulation in fishes. In: Hoar, W. S., Randall, D. J. (ed.) Fish physiology, Vol. 10, Pt A. Academic Press Inc, Orlando, Florida, p. 315-401

Herwig, N. (1979). Handbook of drugs and chemicals used in the treatment of fish diseases. Bannerstone House, Springfield, Illinois

Holeton, G. F., Neumann, P., Heisler, N. (1983). Branchial ion exchange and acid-base regulation after strenuous exercise in rainbow trout (Salmo gairdneri). Respir. Physiol. 51: 303-318

Hugo, W. B. (1967). The mode of action of antibacterial agents. J. appl. Bacteriol. 30: 17-50

Isaia, J. (1984). Water and nonelectrolyte permeation. In: Hoar, W. S., Randall, D. J. (ed.) Fish physiology, Vol. 10, Pt B. Academic Press. Inc., Orlando, Florida, p. 1-38
James, A. M. (1964). Surface-active agents in microbiology In: Surface activity and the microbial cell. S. C. I. Monograph no. 19. Society of Chemical Industry, London

Jørgensen, P. L. (1975). Isolation and characterization of the components of the sodium pump. Q. Rev. Biophys. 7: $239-274$

Karlsson, J., Saltin, B. (1971). Oxygen deficit and muscle metabolites in intermittent exercise. Acta Physiol. scand. 82: $115-122$

Kreibich, G., Hubbard, A. L., Sabatini, D. D. (1974). On the spatial arrangement of proteins in microsomal membranes from rat liver. J. Cell Biol. 60: 616-627

Lemke, A. E., Mount, D. I. (1963). Some effects of alkyl benzene sulfonate on the bluegill, Lepomis macrochirus. Trans. Am. Fish. Soc, 92: 372-378

Mallatt, J. (1985). Fish gill structural changes induced by toxicants and other irritants: a statistical review. Can. J. Fish. Aquat. Sci. 42: 630-648

Malte, H. (1986). Effects of aluminum in hard, acid water on metabolic rate, blood gas tensions and ionic status in the rainbow trout. J. Fish Biol. 29: 187-198

Malte, H., Weber, R. E. (1985). A mathematical model for gas exchange in the fish gill on non-linear blood gas equilibrium curves. Respir Physiol. 62: 359-374

Mazeaud, M. M., Mazeaud, F. (1981). Adrenergic responses to stress in fish. In: Pickering, A. D. (ed.) Stress and fish. Academic Press, Toronto, p. 49-75

Milligan, C. L., Wood, C. M. (1982). Disturbances in haematology, fluid volume distribution and circulatory function associated with low environmental $\mathrm{pH}$ in the rainbow trout, Salmo gairdneri. J. exp. Biol. 99:397-415

Nikinmaa, M. (1982). Effects of adrenaline on the red cell volume and concentration gradient of protons across the red cell membrane in the rainbow trout, Salmo gairdneri. Molec. Physiol. 2: 287-297

Rackley, W R. (1946). Trout and gill bacteria: determinations and countermeasures. Lookout mountain trout hatchery, Wheatridge, Colorado

Railo, E., Nikinmaa, M., Soivio, A. \{1985\}. Effects of sampling on blood parameters in the rainbow trout, Salmo gairdneri Richardson. J. Fish Biol. 26: 725-732

Randall, D., Daxboeck, C. (1984). Oxygen and carbon dioxide transfer across fish gills. In: Hoar, W. S., Randall, D. J. (eds.) Fish physiology, Vol. 10, Pt A. Academic Press, Inc., Orlando, Florida, p. 263-314

de Renzis, G., Bornancin, M. (1984). Ion transport and gill ATPases. In: Hoar, W. S., Randall, D. J. (eds.) Fish physiology, Vol. 10, Pt B. Academic Press, Inc., Orlando, Florida, p. $65-104$

Satchell, G. H. (1984). Respiratory toxicology of fishes. In: Weber, L. J. (ed.) Aquatic toxicology, Vol. 2. Raven Press, New York, p. 1-50

Schmid, O. J., Mann, H. (1961). Action of a detergent (Dodecylbenzenesulphonate) on the gills of the trout. Nature, Lond. 192: 675

Skidmore, J. F., Tovell, P. W. A. (1972). Toxic effects of zinc sulphate on the gills of rainbow trout. Wat. Res. 6: $217-230$

Smart, G. (1976). The effect of ammonia exposure on gill structure of the rainbow trout (Salmo gairdneri). J. Fish Biol. 8: 471-475

Spry, D. J., Wood, C. M. (1984). Acid-base, plasma ion and blood gas changes in rainbow trout during short term toxic zinc exposure. J comp. Physiol. 154B: 149-158

Turner, J. D., Wood, C. M., Clark, D. (1983). Lactate and proton dynamics in the rainbow trout (Salmo gairdneri). J. exp. Biol. 104: 247-268 
Wardle, C. S. (1978). Non-release of lactic acid from anaerobic swimming muscle of plaice, Pleuronectes platessa L.: a stress reaction. J exp. Biol. 77: 141-155

Wilson, J. A. (1982). Principles of animal physiology, 2 nd edn. Collier Macmillan Canada, Ltd, p. 173-174
Wood, C. M. (1988). The physiological problems of fish in acidic waters. In: Morris, R., Brown, D. J. A., Taylor, E. W. Brown, J. A. (eds.) Acid toxicity and aquatic animals, Society for experimental biology seminar series. Cambridge University Press, Cambridge, p. 125-152

Responsible Subject Editor: Dr G. Peters; accepted for printing on May 16, 1989 